Ethos (Jurnal Penelitian dan Pengabdian Masyarakat): 226-232

\title{
Pelatihan Manajemen Konten Berbasis E-Learning bagi GuRU - Guru Pondok Pesantren Kelurahan Sasak Panjang, Kabupaten Bogor
}

\author{
${ }^{1}$ Theresia Wati, ${ }^{2}$ Henki Bayu Seta \\ ${ }^{1}$ Teknik Informatika, ${ }^{2}$ Manajemen Informatika, UPN “Veteran” Jakarta \\ Jl. RS Fatmawati, Jakarta Selatan 12450 \\ email : ${ }^{1}$ theresia.atha@gmail.com, ${ }^{2}$ henkiseta@gmail.com
}

\begin{abstract}
The learning process performed by teachers generally using the lecture method or deliver the learning materials orally. Communication is done in one way, and if there are learners who pay less attention to the lesson, they will be missed the lesson. One way to overcome this problem is to use information technology-based learning media (e-learning). The software used is LMS (Learning Management System) MOODLE based on Open Source and Ms. Office Applications Power Point for learning the content creation. The aim of the program is to improve the ability of teachers in mastering the information technology (ICT), to train the teachers to create teaching material content of ICT-based, and to allow teachers to update teaching materials in the future. The training was conducted using the method of learning by doing, where each participant can learn by direct practice. The activities done in the project were collecting data on teachers with a minimum requirement of the ability to run a computer properly, training on teaching materials based on office applications using Ms. Power Point, and training in the use of e-learning for teachers in Islamic boarding school of Taruna Insani. Training undertaken include the course setting and management. During the implementation of the training, participants will be given assistance or consultation for those who are having trouble.
\end{abstract}

Keywords: Information technology, e-learning, learning content

\begin{abstract}
Abstrak. Proses pembelajaran yang dilakukan oleh guru menggunakan metode ceramah atau penyampaian bahan pelajaran secara lisan, komunikasi dilakukan secara satu arah dan jika ada peserta didik yang kurang memperhatikan pelajaran, maka peserta didik akan ketinggalan. Salah satu cara mengatasi permasalahan tersebut adalah dengan menggunakan media pembelajaran berbasis teknologi informasi (e-learning). Perangkat lunak yang digunakan adalah perangkat lunak LMS (Learning Management System) MOODLE yang berbasis Open Source dan Aplikasi Perkantoran Ms. Power Point untuk pembuatan konten pembelajaran. Tujuan dari program ini meningkatkan kemampuan guru dalam bidang penguasaan teknologi informatika (TIK), memberikan pelatihan bagi guru untuk membuat content bahan ajar berbasis TIK dan memudahkan guru untuk mengupdate bahan ajar di kemudian hari. Pelatihan dilakukan dengan menggunakan metode learning by doing, dimana setiap peserta dapat belajar dengan cara langsung mempraktekkan. Kegiatan yang dilakukan yaitu melakukan pendataan guru-guru dengan syarat minimal mampu mengoperasikan komputer dengan baik, melakukan pelatihan pembuatan kontent bahan ajar berbasis aplikasi perkantoran dengan menggunakan Ms. Power Point, dan melakukan pelatihan penggunaan e-learning untuk guru - guru di pondok pesantren Taruna Insani. Pelatihan yang dilakukan antara lain setting cource dan manajemen course. Selama pelaksanaan pelatihan, peserta akan diberikan pendampingan atau konsultasi bagi peserta yang mengalami kesulitan.
\end{abstract}

Kata Kunci : Teknologi informasi, E-learning, konten, pembelajaran 


\section{Pendahuluan}

Salah satu kewajiban guru adalah meningkatkan kompetensi dibidang teknologi informasi dan komunikasi (TIK). Saat ini proses pembelajaran yang dilakukan oleh guru menggunakan metode ceramah atau penyampaian bahan pelajaran secara lisan. Beberapa kekurangan diantaranya komunikasi dilakukan secara satu arah dan jika ada peserta didik yang kurang memperhatikan pelajaran, maka peserta didik akan ketinggalan. Kegiatan pembelajaran akan menjadi membosankan bila digunakan terlalu lama serta sulit untuk mengetahui apakah siswa mengerti dan tertarik dengan materi yang diajarkan. Salah satu cara untuk mengatasinya dengan menggunakan pembelajaran blended learning, menggunakan tools Learning Management System Moodle. Peserta pelatihan e-learning terdiri atas 18 peserta guru, setiap guru telah memiliki telah memiliki perangkat keras berupa laptop namun belum mampu menerapkan pembelajaran e-learning berbasis ICT. Transfer IbM yang akan dilakukan adalah menerapkan dan melatih guru untuk sistem pembelajaran e-learning berbasis ICT. Luaran program adalah peningkatan kemampuan guru dalam menerapkan pembelajaran elearning untuk mewujudkan konsep sekolah berbasis teknologi informasi dan komunikasi sehingga kualitas belajar mengajar pada mitra meningkat. Dalam pelatihan ini, guru-guru akan diajarkan dan didampingi selama pelatihan. Pelatihan ini menggunakan LMS Moodle yang berbasis open source.

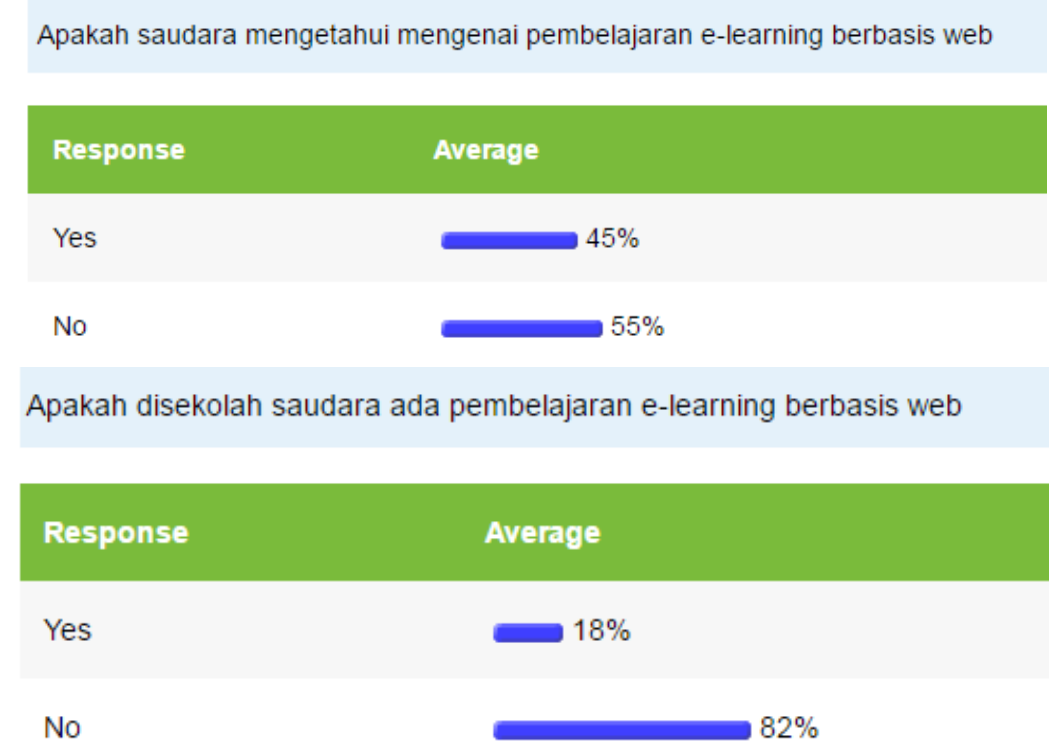

Gambar 1. Angket Pra Abdimas

Berdasarkan angket awal yang telah dilakukan terhadap 18 guru SMPIT Taruna Insani Pesantren Tahfidz Modern 55\% responden menyatakan belum mengetahui mengenai pembelajaran elearning berbasis web. Dan $82 \%$ responden menyatakan belum ada pembelajaran e-learning berbasis web dan membutuhkan pembelajaran e-learning berbasis web untuk membantu proses kegiatan belajar mengajar.

Merujuk pada hasil analisis yang telah dilakukan, permasalahan utama yang dihadapi oleh mitra adalah bagaimana meningkatkan kompetensi guru di bidang teknologi informasi dan komunikasi, bagaimana membuat presentasi bahan ajar yang lebih menarik sehingga timbul minat peserta didik untuk mempelajari, bagaimana guru dapat melakukan unggah dan mengupdate bahan ajar yang telah disipersiapkan. Bagaimana guru dapat melakukan manajemen course dengan menggunakan e-learning. 


\section{Metode}

Pelatihan ini akan dilakukan dengan metode pembelajaran learning by doing untuk mendukung pengembangan pengetahuan yang dimiliki guru-guru secara mandiri. Penggunaan kedua metode pembelajaran diharapkan membentuk tanggung jawab dan kemandirian. Solusi dari program Pengabdian Kepada Masyarakat (PKM) FIK-UPNVJ ini adalah memberikan keterampilan dalam pemanfaatan teknologi informasi kepada guru pondok pesantren Taruna Insani yang berada di lingkungan Desa Sasak Panjang, memberikan pelatihan manajemen cource dan manajemen content dengan menggunakan e-learning.

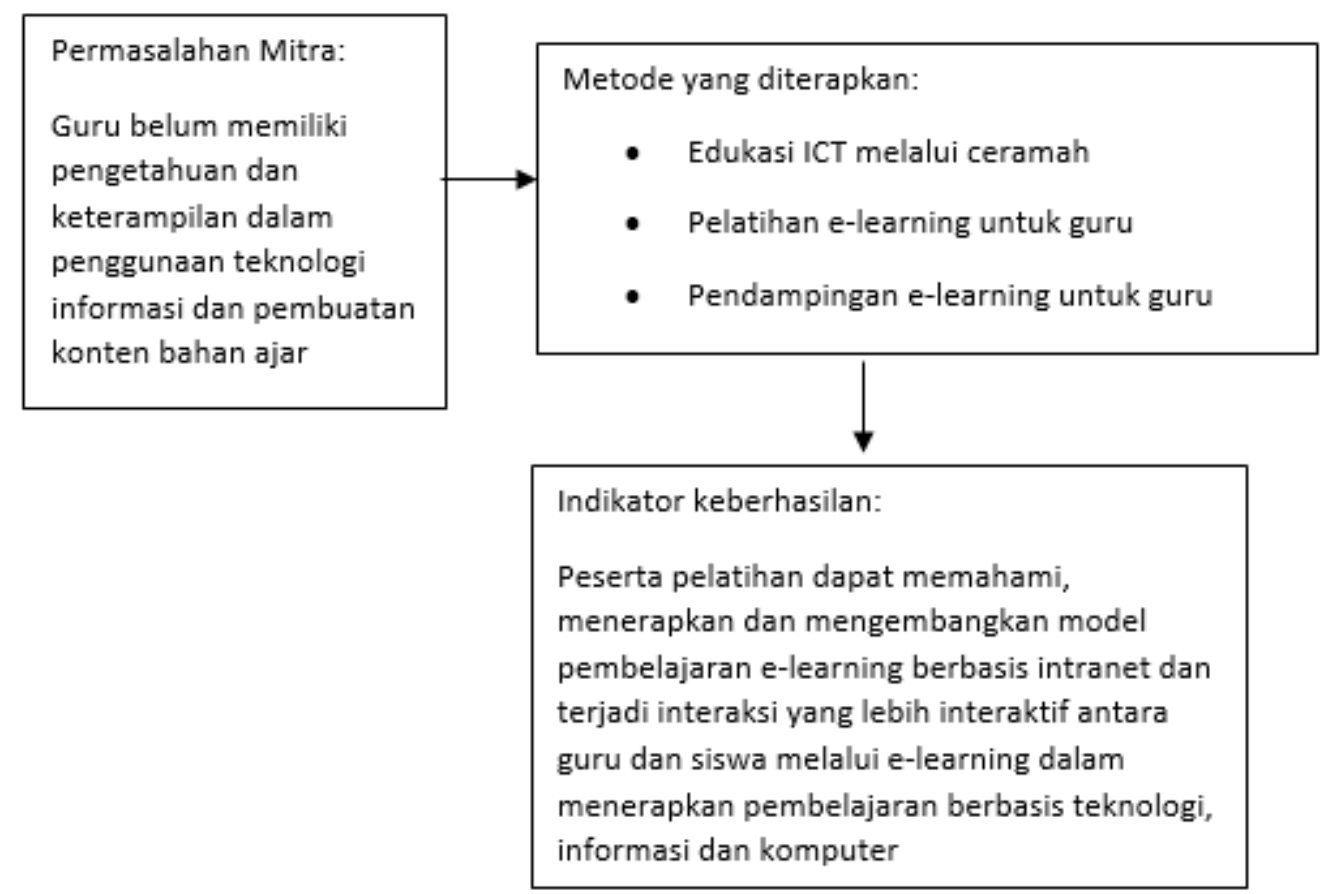

Gambar 2. Tahapan Kegiatan Abdimas

Rencana kegiatan program Iptek bagi Masyarakat adalah melakukan pelatihan pembuatan bahan ajar yang menarik dan interaktif, pelatihan pengenalan tentang $e$-learning dan Moodle, penggunaan e-learning untuk guru yaitu pelatihan manajemen konten (unggah materi), pelatihan manajemen user (update profil guru) dan pelatihan pembuatan quiz /ujian online dan pembuatan forum diskusi. Tahap akhir adalah tahapan pelaporan. Hasilnya semua guru sudah mengetahui penggunaan dan manfaat e-learning serta membuat mata pelajaran, profil guru, up load materi, dan membuat soal dalam e-learning.

\section{Hasil dan Pembahasan}

Kegiatan pengabdian masyarakat terdiri dari beberapa kegiatan terdiri dari:

1. Tanggal 24 Juli 2017 diadakan rapat koordinasi pelaksanaan kegiatan pengabdian masyarakat antara pengabdi dengan pihak sekolah SMPIT Taruna Insani yaitu Kepala Sekolah dan 2 Wakil Kepala Sekolah. Hal-hal yang dibicarakan antara lain waktu pelaksanaan, persiapan yang harus dimiliki guru sebelum pelatihan diantaranya adalah bahan ajar yang akan di unggah, beberapa contoh soal tugas atau quiz yang akan di buatkan bank soal e-learning baik soal pilihan ganda maupun essai.

2. Tanggal 11 - 18 Agustus 2017 diadakan kegiatan pengabdian masyarakat. Pelatihan diberikan dalam beberapa tahapan pelatihan yang mulai dilaksanakan setiap hari jum'at tanggal 11 dan 18 Agustus 2017 mulai pukul 9.00 sampai dengan pukul 16.00 WIB. 
3. Tanggal 11 Agustus 2017 ada beberapa kegiatan yang dilakukan diantaranya adalah melakukan survey awal dengan menggunakan kuesioner melalui e-learning, pelatihan pembuatan bahan ajar yang interaktif dan menarik dengan menggunakan aplikasi perkantoran, melakukan perubahan profil guru, dan melakukan unggah materi ajar dengan mengunakan e-learning. Pengaturan Profil Pengguna E-learning (update profile), Mengatur Banyaknya Pertemuan dalam satu semester (per topik atau per minggu) dan Enroll User digunakan pengajar untuk mendaftarkan peserta didik ke dalam sebuah mata pelajaran yang diajarkan oleh guru tersebut agar siswa dapat mengakses materi mata pelajaran yang dia ambil dan ikut serta dalam pembelajaran menggunakan e-learning. Melakukan unggah bahan ajar dalam bentuk file (.docx, .xls, .ppt, .pdf). Memperbaharui (update), memindahkan (drag) dan menghapus (delete) konten bahan ajar.

4. Berdasarkan angket yang dilakukan diawal pelatihan terlihat ketertarikan guru untuk menggunakan e-learning sebagai alat bantu proses kegiatan belajar mengajar. Sehingga sistem pembelajaran yang dilakukan adalah blended learning. Fasilitas yang digunakan antara lain unggah bahan ajar, diskusi antara guru dan siswa dengan mengguanakan forum diskusi, pelaksanaan ujian atau quiz, unggah tugas oleh siswa dan guru melakukan penilaian langsung melalui $e$ - learning. Sehingga memudahkan guru untuk dapat secara langsung melihat nilai rata-rata tugas yang diberikan selama satu semester.

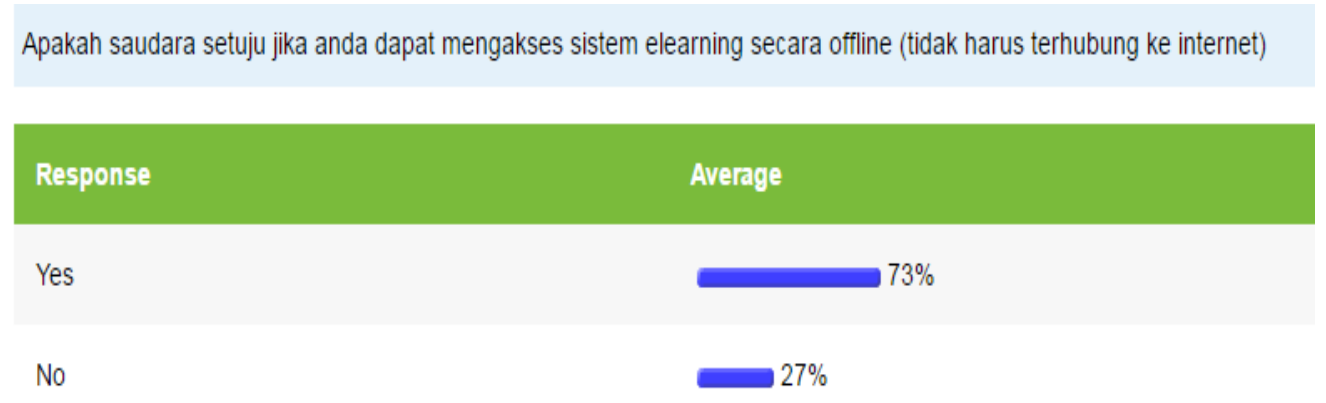

Gambar 3. Hasil Angket Awal Pelatihan

Sebanyak $73 \%$ responden guru setuju untuk menggunakan e-learning secara offline atau tidak terhubung ke internet atau menggunakan jaringan intranet. Hal ini dikarenakan SMPIT Taruna Insani merupakan sekolah boarding school atau pesantren yang memegang teguh nilai agama. Dengan e-learning berbasis intranet, guru dan siswa dapat meningkatkan proses kegiatan belajar mengajar serta siswa tidak terkoneksi dengan jaringan luar (internet) sehingga siswa tidak mengakses konten yang tidak berhubungan dengan pendidikan.

5. Tanggal 18 Agustus 2017 dilakukan pelatihan e-learning dengan materi pembuatan drop box untuk siswa melakukan unggah tugas melalui e-learning, menetapkan batas waktu unggah tugas dan melakukan penilaian terhadap tugas yang telah di unggah siswa. Melakukan pembentukan Bank soal yang akan dibuatkan quiz online, baik berupa soal essay maupun pilihan ganda. Untuk soal pilihan ganda, nilai siswa dapat langsung diperoleh dan dilihat oleh siswa, hal ini karena guru menetapkan jawaban yang benar beserta nilainya. Pelatihan selanjutnya yaitu pembuatan Forum diskusi. Melalui forum diskusi guru dan siswa dapat saling berkomunikasi dan siswa dapat bertanya langsung melalui guru dengan menggunakan e-learning.

Berikut ini adalah gambaran suasana pelatihan manajemen konten e-learning: 

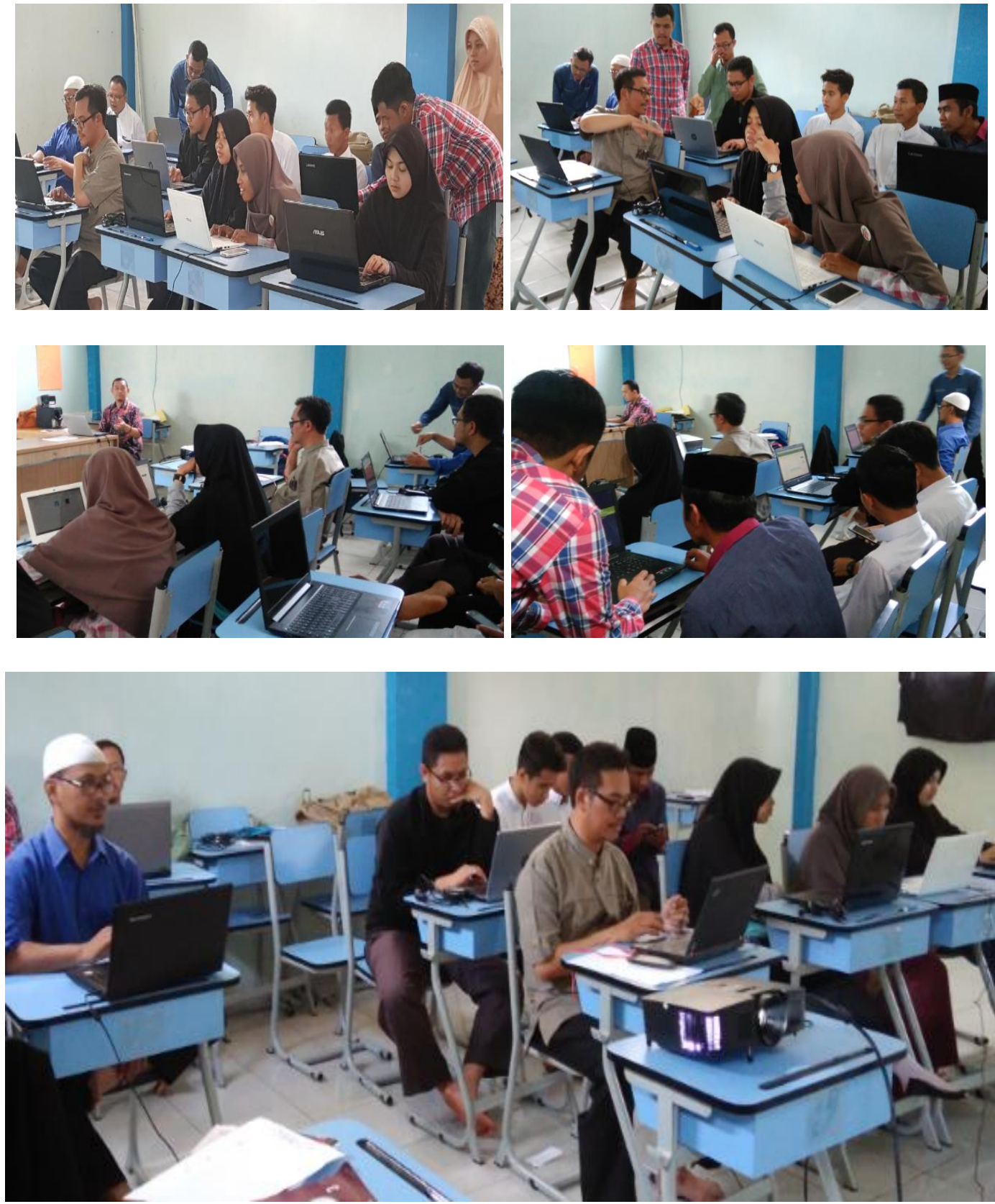

Gambar 4. Suasana Pelatihan

\section{Simpulan dan rekomendasi}

\section{Simpulan}

Saat ini proses pembelajaran yang dilakukan oleh guru menggunakan metode ceramah atau penyampaian bahan pelajaran secara lisan. Metode pengabdian masyarakat yang diterapkan yaitu Edukasi ICT melalui ceramah, Pelatihan e-learning untuk guru dan Pendampingan $e$ learning. Pelatihan e-learning dilaksana kan pada tanggal 11 dan 18 Agustus 2017 bertempat di SMPIT Taruna Insani, Sasak Panjang, Bogor. Tujuan kegiatan pengabdian masya-rakat ini adalah untuk memberikan pengetahuan dan keterampilan guru mengguna-kan e-learning berbasis intranet. Jumlah guru yang terdaftar mengikuti pelatihan sebanyak 18 orang guru. Sebanyak $73 \%$ responden guru setuju untuk menggunakan e-learning secara offline atau tidak terhubung ke internet atau menggunakan jaringan intranet. Dengan e-learning berbasis intranet, guru dan siswa dapat meningkatkan proses kegiatan belajar mengajar serta siswa tidak 
terkoneksi dengan jaringan luar (internet) sehingga siswa tidak mengakses konten yang tidak berhubungan dengan pendidikan.

\section{Rekomendasi}

Untuk lebih meningkatkan minat guru untuk menggunakan pembelajaran berbasis $e$ learning diperlukan keseriusan pihak manajemen sekolah untuk lebih mengoptimalkan penggunaan e-learning. Sehingga proses kegiatan belajar mengajar menjadi lebih interaktif dan mendukung proses kegiatan belajar.

\section{Ucapan Terimakasih}

Penulis mengucapkan terimakasih kepada Lembaga Penelitian dan Pengabdian Masyarakat (LPPM), UPN "Veteran" Jakarta yang telah membiayai kegiatan pengabdian masyarakat. Dan kepada Yayasan Insan Madani, SMP IT Taruna Insani, Sasak Panjang, Bogor yang telah memberikan fasilitas tempat dan waktu untuk pelaksanaan pengabdian masyarakat.

\section{Daftar pustaka}

Agustina, Merry.2013. Pemanfaatan E-Learning sebagai Media Pembelajaran. Seminar Nasional Aplikasi Teknologi Informasi (SNATI) 2013, Yogyakarta, 15 Juni 2013

Ali, M, E-learning in Indonesian Education System. A paper presented at Seminar-Workshop on E-learning : The Seventh Programming Cycle of APEID Activities, 30 August-6 September 2004 in Tokyo and Kyoto, Japan

A. Merry, "Pemanfaatan E-Learning Sebagai Media Pembelajaran", Seminar Nasional Aplikasi Teknologi Informasi (SNATI) 2013, Yogyakarta, 15 Juni 2013, pp. G8-G12.

Bates, A. W. Technology, Open Learning and Distance Education. London: Routledge, 1995

Brown, Mary Daniels. Education World: Technology in the Classroom: Virtual High Schools, Part 1, The Voices of Experience. http://www.education-world.com/a_tech/tech052.shtml ( 16 April 2016).

Harahap, Seprida Hanum. 2015. Pemanfaatan E-Learning Berbasis Lcms Moodle Sebagai Media Pembelajaran Untuk Mata Kuliah( Sistem Informasi Akuntansi. Jurnal Riset Akuntansi dan Bisnis, Vol.15, No.1, Maret 2015.

Koswara, E. Konsep Pendidikan Tinggi Berbasis E-learning : Peluang dan Tantangan. Prosiding Konferensi Nasional Teknologi Informasi dan Komunikasi Indonesia ITB, 3-4 Mei 2005

Kosasi, Sandy. 2015.Perancangan E-learning Untuk Meningkatkan Motivasi Belajar Guru dan Siswa. Prosiding Seminar Nasional Pendidikan Teknik Informatika (SENAPATI 2015). Sigaraia - Bali, 12 September 2015

Natakusumah, E.K. Multimedia sebagai sarana pembelajaran; Lokakarya Multimedia sebagai sarana pembelajaran metode learning based; DUE-Like TPB ITB, 13 Nopember 2002.

Natakusumah, E.K. Teknologi informasi pada pendidikan jarak jauh, Orasi Ilmiah pada Wisuda STMIK Bandung, 12 Januari 2002, Grand Aquila Hotel, Nusantara Ball Room, Bandung.

Newsletter of Open and Distance Learning Quality Council, October 2001. http://www.odlqc.org.uk/odlqc/n19-e.html (16 September 2002)

Siahaan, S. 2004. E-learning (Pembelajaran Elektronik) Sebagai Salah Satu Alternatif Pembelajaran http://www.depdiknas.go.id/Jurnal/42/ sudirman.htm (3 November 2006)

Suharyanto dan Adele B. L. Mailangkay. 2016. Penerapan E-Learning sebagai alat bantu mengajar dalam dunia pendidikan. IKPIA Perbanas, Jakarta, Indonesia. Jurnal Ilmiah Widya . ISSN 2337-6686 Volume 3 Nomor 4 Agustus - Desember 2016

Tiara.2015. Pengembangan Media E-Learning Berbasis Moodle Pada Kompetensi Dasar Jurnal Khusus Untuk Siswa Kelas Xii Ips Semester Gasal Di Sma Negeri 4 Jember . Prosiding Semiar Nasional Pendidikan Ekonomi \& Bisnis Fakultas Keguruan dan Ilmu Pendidikan Universitas Sebelas Maret Surakarta.

Y. Mohammad, "E-learning Sebagai Media Pembelajaran Interaktif Berbasis Teknologi Informasi”, Jurnal Ilmiah Foristek Vol. 2, No. 1, Maret 2012, pp. 143-152 
232 Theresia Wati, et al.

Zyainuri, M. Eko, "Penerapan E-Learning Moodle Untuk Pembelajaran Siswa yang Melaksanakan Prakerin", Jurnal Pendidikan Vokasi, Vol. 2, No. 3, November 2012, pp. 410-426. 